\title{
Kesaksian Perempuan: \\ Telaah Terhadap Status dan Kedudukan Perempuan dalam Hukum Islam
}

\author{
Moh. Ulumuddin \\ STAI At-Tahdzib Ngoro Jombang \\ Email: mohammadulumuddin@gmail.com
}

\begin{abstract}
A discussion of the relationship betwen men and women which is not only discuss biological differences, but also their social role differences. So, in the Islamic Law about the value of women testimony than men is the main differences in muamalah case and islamic family law case.

Suatu diskusi hubungan antara para laki-laki dan perempuan yangtidak hanya mendiskusikan perbedaan segi biologi, tetapi juga melibatkan perbedaan peranan sosial mereka. Maka, di dalam Hukum Islam tentang nilai kesaksian wanitawanita dibanding orang laki-laki merupakan pokok-pokok penting perbedaan di dalam kasus muamalah hukum dan hukum perkawinan Islam
\end{abstract}

Keywords: kesaksian wanita, fiqh muamalah, and fiqh munakahat

\section{Pendahuluan}

Dalam diskursus Islam dan jender, pembahasan tentang persaksian perempuan merupakan satu dari sekian tema, yang hingga saat ini masih cukup aktual. (Nasaruddin Umar, 2001). Beberapa kajian telah menunjukkan bagaimana penafsiran keagamaan yang bias jender memberikan kontribusi dalam pelabelan negatif terhadap perempuan. Menurut Mahfudh, penilaian agama yang bias terhadap perempuan tersebut berawal dari tiga buah asumsi dasar tentang keyakinan dalam beragama. Pertama, asumsi dogmatik yang secara eksplisit menempatkan perempuan sebagai pelengkap. Kedua, dogma bahwa bakat moral etik perempuan lebih rendah. Ketiga, pandangan materialistik, ideologi masyarakat Makah pra-Islam yang memandang rendah peran perempuan dalam proses produksi.

Tanpa bermaksud mengabaikan signifikansi pendekatan teologis dalam konteks Indonesia, menarik dicatat pandangan Wahid, yang menyatakan hukum Islam -baca fikih- jauh tertinggal di belakang realitas sosial mayarakat. Menurutnya, isu kesetaraan jender hakikatnya terletak pada hak asasi manusia (al-kulliyyât al-khamsah), dengan lebih memempatkan persamaan di muka hukum (equality before the law) sebagai inti dari persamaan dalam memperoleh kesempatan (equality of opportunity). (Abdurahman Wahid, 2007) Pandangan ini berdasarkan fenomena umum masyarakat Indonesia, yang tidak mempersoalkan kiprah perempuan dalam publik dan memberikan akses luas misalnya dalam pekerjaan, pendidikan, politik, dan hukum.

Berbeda dengan fakta sosial masyarakat muslim Indonesia. Dalam literatur fikih yang beredar secara luas, masih banyak ditemukan pemikiran yang mencerminkan pengukuhan terhadap tradisi patriarki. Demikian ini dapat dipahami, karena betapapun keinginan fuqaha untuk menyajikan fikih yang ideal, tentu tidak lepas dari kondisi sosial budaya tempat fikih diproduk. Dalam hal ini, gambaran pemikiran fikih Imam 
Abu Hanifah yang lebih bercorak rasional ketimbang Imam Maliki dapat dijadikan contoh.

Dengan landasan teoritis di atas, artikel ini menfokuskan pembahasan tentang kesaksian perempuan di muka hukum. Dan dengan mempertimbangkan ketentuan Kompilasi Hukum Islam di Indonesia, yang tidak menerima kesaksian perempuan dalam perkawinan, analisa terhadap dalil-dalil fikih diperkaya dengan mengemukakan pendapat alternatif ulama dalam memahami ayat tentang kesaksian, yang lebih menekankan keterpercayaan seseorang daripada kuantitas saksi.

\section{Pembagian Hukum Muamalah dalam Fikih}

Untuk dapat melakukan kajian ilmiah atas materi fikih, diperlukan wawasan konseptual tentang taksonomi fikih yang secara luas telah diterima oleh ilmuan/ fuqaha'. Dalam wacana modern, sebagaimana penjelasan Khalaf dan Zuhayli, taksonomi fikih untuk bidang mu'amalah terbagi menjadi tujuh bagian, yaitu:

1. Al-A $\underline{h k a m}$ al-Ahwal al-Shakhsiyah (hukum perdata), berkenaan dengan kekerabatan Yang mengatur hubungan suami-isteri, antar kerabat, dan kewarisan (terdapat 70 ayat dalam al-Qur'an);

2. Al-Ahkam al-Madaniyah (hukum antar individu/warga); berkenaan dengan perbuatan antar individu, yang meliputi jual-beli, gadai, agunan, perseroan, dan sebagainya, yang bermaksud untuk mengatur hubungan kehartaan antar individu dan melindungi hak seseorang (terdapat 70 ayat);

3. Al-Ahkam al-Jinaiyah (hukum pidana), berkenaan dengan kejahatan dan sanksi hukumnya, dan bermaksud untuk melindungi kehidupan manusia, hartanya, dan hakhaknya, dan untuk membatasi hubungan antara terpidana dengan pemidana dan (terdapat 30 ayat);

4. Al-A $\underline{h k a m}$ al-Murafa'at (hukum acara), berkenaan dengan proses peradilan, keputusan, kesaksian, dan sumpah, bermaksud untuk mengatur tindakantindakan agar tercipta keadilan di antara sesama manusia (terdapat 13 ayat);

5. Al-Ahkam al-Dusturiyah (hukum perundangan), berkenaan dengan tatacara hukum dan sumber-sumbernya, bermaksud untuk membatasi hubungan antara pemerintah dan rakyat, dan pernyataan hak-hak Individu dan masyarakat (terdapat 10 ayat);

6. Al-Ahkam al-Dawliyah (hukum kenegaraan); hokum mengenai relasi antara negara dan warganya, juga dengan negara-negara lain; berkenaan dengan (a) hubungan peinerintah Islam dengan negara-negara lain, yakni undang-undang (qanun) umum kenegaraan, (b) hal-ihwal selain muslim yang berada dalam sistem pemerintahan Islam, yakni undang-undang khusus kenegaraan, bermaksud untuk membatasi hubungan pemerintahan Islam dengan negara-negara lain dalam perdamaian dan peperangan dan membatasi hubungan masyarakat Islam dengan masyarakat lainnya dalam negara Islam (terdapat 25 ayat) dan;

7. Al-Ahkam al-Iqtishadiyah wa al-Maliyah (hukum kehartabendaan), berkenaan dengan hak-hak kehartaan individu-individu dan pertanggungjawabannya dalam pengaturan harta, serta hak-hak negara dan kewajiban-kewajibannya, bermaksud untuk mengatur hubungan kehartaan antara orang kaya dan orang miskin, dan antara Negara dan individu individu (terdapat 10 ayat).

Dalam pandangan usul fiqh, ketujuh bidang di atas termasuk dalam wilayah hukum muamalah yang bermaksud untuk mengatur hubungan antar sesama manusia, apakah sebagai individu maupun sebagai anggota masyarakat. Ini merupakan hukum ketiga yang terdapat dalam al-Qur'an. Pembagian lengkapnya adalah (1) hukum keyakinan (al-ahkam 
al-i'tiqâdiyah), (2) hukum akhlak (al-ahkam al-khuluqiyah); dan (3) hukum perbuatan (alahkam al-'amaliyah).

Hukum keyakinan berkenaan dengan kewajiban bagi mukallaf untuk meyakini Allah, para malaikat-Nya, kitab-kitab-Nya, rasul-rasul-Nya, dan hari akhir. Hukum akhlak berkenaan dengan kewajiban bagi mukallaf untuk menghiasi diri dengan perilaku yang terpuji dan menghindar dari perilaku yang tercela. Sedangkan hukum perbuatan berkenaan dengan kewajiban bagi mukallaf, yang meliputi perkataan, perbuatan, transaksi, dan tindakan. Hukum terakhir ini disebut fikih al-Qur'an, yang memerlukan ilmu usul fiqh. Hukum ini terbagi menjadi dua macam, yaitu hukum `ibadah dan hukum mu'amalah.

Hukum ibadah meliputi shalat, puasa, zakat, haji, ujar (nadhar), sumpah, dan sebagainya, yang bertujuan untuk mengatur hubungan manusia dengan Tuhannya. Sedangkan hukum mu'amalah sebagaimana penjelasan di atas. Kemudian, Al-Khatib, dengan merujuk pada konvensi hukum di kalangan ahli fikih, menyatakan bahwa muatan fikih secara rinci terbagi menjadi delapan bidang, yaitu (1) hukum ibadah, (2) hukum alahwal al-shakhsiyah yang meliputi hukum keluarga dan kewarisan, (3) hukum mu'amalah madaniyah, (4) hukum maliyah wa al-iqtishâdiyah, (5) hukum pidana, (6) hukum murafa'at, (7) hukum dusturiyah, dan (8) hukum dauliyah.

Hukum kedua dalam pembagian menurut al-Khatib di atas memperjelas wawasan konseptual bahwa sejumlah subjek materi yang terhimpun dalam hukum al-ahwal alshakhsiyah terklasifikasi menjadi dua, yaitu hukum keluarga/pemikahan dan hukum kewarisan. Kemudian hukum ketiga, hukum muamalah madaniyah mengatur hubungan kehartaan antar individu. Sedangkan hukum keempat, hukum maliyah wa al-Iqtishâdiyah mengatur relasi kehartaan antara negara dan warganya, dan antara si kaya dan si miskin. Penjelasan ini diperlukan kaitannya dengan pembatasan masalah penelitian yang fokus terhadap kesaksian perempuan dalam perkawinan.

\section{A. Prinsip-Prinsip Kesetaraan Jender}

Ada beberapa variabel yang dapat digunakan sebagai standar dalam menganalisa prinsip-prinsip kesetaraan jender dalam al-Quran. Variabel-variabel tersebut antara lain sebagai berikut:

\section{Laki-laki dan perempuan sama-sama sebagai hamba.}

Salah satu tujuan penciptaan manusia adalah menyembah kepada Tuhan, sebagaimana disebutkan dalam Q.,s. Al-Zariyat/51:56:

Dan Aku tidak menciptakan jin dan manusia melainkan supaya mereka menyembah-Ku

Dalam kapasitas manusia sebagai hamba, tidak ada perbedaan antara laki-laki dan perempuan. Keduanya mempunyai potensi dan peluang yang sama untuk menjadi hamba ideal. Hamba ideal dalam al-Quran diistilahkan dengan orangorang yang bertaqwa (Muttaqin). Sebagaimana disebutkan di dalam Q.,s. AlHujurat/49:13:

Hai manusia, sesungguhnya kami menciptakan kalian dari seorang laki-laki dan seorang perempuan dan menjadikan kalian berbangsa-bangsa dan bersuku-suku supaya kalian saling mengenal. Sesungguhnya orang yang paling mulia di antara kalian di sisi Alloh ialah orang yang paling bertakwa di antara kalian. Sesungguhnya Alloh Maha Mengetahui lagi Maha Mengenal.

Dalam kapasitas sebagai hamba, laki-laki dan perempuan akan mendapatkan penghargaan dari Tuhan sesuai dengan kadar pengabdiannya, sebagaimana disebutkan dalam Q.,s. al-Nahl/16:97: 
Barang siapa yang mengerjakan amal saleh, baik laki-laki maupun perempuan dalam keadaan beriman, maka sesungguhnya akan kami berikan kepadanya kehidupan yang baik dan sesungguhnya akan Kami beri balasan kepada mereka dengan pahala yang lebih baik dari apa yang telah mereka kerjakan.

\section{Laki-laki dan perempuan sebagai khalifah di bumi}

Maksud dan tujuan penciptaan manusia di muka bumi ini adalah, di samping untuk menjadi hamba (abid)) yang tunduk dan patuh serta mengabdi kepada Alloh swt., juga untuk menjadi khalifah di bumi (khalifa fil ardl). Kapasitas manusia sebagai khalifah di bumi ditegaskan dalam Q.,s. Al-An'am/6:165:

Dan Dialah yang menjadikan kalian penguasa-penguasa di bumi dan Dia meninggalkan sebagian kalian atas sebagian (yang lain) beberapa derajat, untuk mengujimu tentang apa yang diberikan-Nya kepada kalian. Sesungguhnya Tuhan kalian amat cepat siksaan-Nya, dan sesungguhnya Dia Maha Pengampun lagi Maha Penyayang.

Dalam ayat lain disebutkan dalam Q.,s. Al-Baqarah/2:30:

Ingatlah ketika Tuhanmu berfirman kepada para malaikat: "Sesungguhnya Aku hendak menjadikan seorang khalifah di muka bumi". Mereka berkata: "Mengapa Engkau hendak menjadikan (khalifah) di bumi itu orang yang akan membuat kerusakan padanya dan menumpahkan darah, padahal kami senantiasa bertasbih dengan memuji Engkau dan mensucikan Engkau?" Tuhan berfirman: "Sesungguhnya Aku mengetahui apa yang tidak kalian ketahui".

Kata khalifah dalam kedua ayat di atas tidak menunjuk kepada salah satu jenis kelamin atau kelompok etnis tertentu. Laki-laki dan perempuan mempunyai fungsi yang sama sebagai khalifah, yang akan mempertanggung jawabkan tugas-tugas kekhalifahannya di bumi, sebagaimana halnya mereka harus bertanggung jawab sebagai hamba Tuhan.

\section{Laki-laki dan perempuan menerima perjanjian primordial.}

Laki-laki dan perempuan sama-sama mengemban amanah dan menerima perjanjian primordial dengan Tuhan. Seperti diketahui, menjelang seorang anak manusia keluar dari rahim ibunya, ia terlebih dahulu harus menerima perjanjian dengan Tuhannya, sebagaimana disebutkan dalam Q,.s. al-A'raf/7:172:

Dan (ingatlah), ketika Tuhanmu mengeluarkan keturunan anak-anak Adam dari sulbi mereka dan Alloh mengambil kesaksian terhadap jiwa mereka (seraya berfirman): "Bukankan Aku ini Tuhanmu?" Mereka menjawab "Betul (Engkau Tuhan kami), kami menjadi saksi. (Kami lakukan yang sesungguhnya kami (Bani Adam) adalah orang-orang yang lengah terhadap ini (keesaan Alloh).

Menurut Fakh al-Razi, tidak ada seorang pun anak manusia lahir di muka bumi ini yang tidak berikrar keberadaan Tuhan, dan ikrar mereka disaksikan oleh para malaikat.Tidak ada seorangpun yang mengatakan "tidak".

\section{Adam dan Hawa, terlibat secara aktif dalam drama Kosmis}

Semua ayat yang menceritakan tentang drama kosmis, yakni cerita tentang keadaan Adam dan pasangannya di surga sampai keluar ke bumi, selalu menekankan kedua belah pihak secara aktif dengan menggunakan kata ganti untuk dua orang (huma), yakni kata ganti untuk Adam dan Hawa, seperti dapat dilihat dalam beberapa kasus berikut: 
a. Keduanya diciptakan di surga dan memanfaatkan fasilitas surga, disebutkan dalam Q.,s. Al-Baqarah/2:35:

Dan Kami berfirman: "Hai Adam, diamilah oleh kamu dan isterimu surga ini, dan makanlah makanan-makanannya yang banyak lagi baik di mana saja yang kamu sukai, dan janganlah kamu dekati pohon ini, yang menyebabkan kamu termasuk orang-orang yang zalim.

b. Keduanya mendapat kualitas godaan yang sama dari syaitan, dalam Q.,s. Al-A'raf/7:20:

Maka syaitan membisikkan pikiran jahat kepada keduanya untuk menampakkan kepada keduanya apa yang etrtutup dari mereka (yaitu auratnya) dan syaitan berkata: "Tuhan kamu tidak melarangmu dari (mendekati) pohon ini, melainkan supaya kamu berdua tidak menjadi malaikat atau tidak menjadi orang yang kekal (dalam surga).

c. Sama-sama memakan buah khuldi dan keduanya menerima akibat jatuh ke bumi, disebutkan dalam Q.,s. al-A'far/7:22:

Maka syaitan membujuk keduanya (untuk memakan buah itu) dengan tipu daya. Tatkala keduanya telah merasai buah kayu itu, tampaklah bagi keduanya aurat-auratnya, dan mulailah keduanya menutupinya dengan daun-daun surga. Kemudian Tuhan mereka menyeru mereka: "Bukankah Aku telah melarang kamu berdua dari pohon kayu itu dan Aku katakan kepadamu: "Sesungguhnya syaitan itu adalah musuh yang nyata bagi kamu berdua.

d. Sama-sama memohon ampun dan sama-sama diampuni Tuhan, dalam Q.,s. al-A'raf/7:23:

Keduanya berkata: " Ya Tuhan kami, kami telah menganiaya diri kami sendiri, dan jika Engkau tidak mengampuni kami dan memberi rahmat kepada kami, niscaya pastilah kami termasuk orang-orang yang merugi.

e. Setelah di bumi, keduanya mengembangkan keturunan dan saling melengkapi dan saling membutuhkan, disebutkan dalam Q.,s. AlBaqarah/2:187:

Dihalalkan bagi kalian pada malam hari bulan puasa bercampur dengan isteriisteri kalian. Mereka itu adalah pakaian bagimu, dan kalian pun adalah pakaian bagi mereka. Alloh mengetahui bahwasanya kalian mengkhianati diri kamu sendiri, karena itu Alloh mengampuni dan memberi maaf kepadamu.

\section{Laki-laki dan perempuan berpotensi meraih prestasi}

Peluang untuk meraih prestasi maksimum tidak ada perbedaan antara laki-laki dan perempuan, ditegaskan dalam Q.,s. Ali 'Imran/3:195:

Maka Tuhan mereka memperkenankan permohonannya (dengan berfirman), "Sesungguhnya Aku tidak menyia-nyiakan amal orang-orang yang beramal di antara kalian, baik laki-laki atau perempuan, (karena) sebagian kalian adalah turunan dari sebagian yang lain. Maka orang-orang yang berhijrah, yang diusir dari kampung halamannya, yang disakiti pada jalan-Ku, yang berperang dan yang dibunuh, pastilah akan Ku-hapuskan kesalahan-kesalahan mereka dan pastilah Aku memasukkan mereka ke dalam surga yang mengalir sungaisungai di bawahnya sebagai pahala di sisi Allah. Dan Allah pada sisi-Nya pahala yang baik.

\section{B. Kedudukan Saksi dalam Hukum Islam. 1.Pengertian Saksi}


Secara harfiah, syahâdat berarti kabar terhadap sesuatu yang disaksikan, melihat dengan kepala, dan hadir.( Zaki al-Barudi, 2004) Dalam istilah fikih, syahâdat adalah pemberitahuan saksi kepada hakim tentang sesuatu yang dia ketahui dan bukan berdasarkan prasangka, sedang dalam muamalah dikenal dengan kesaksian terhadap hutang piutang yang diketahui kadarnya. Saksi (Syâhid) diartikan dengan orang yang melihat atau mendengar suatu kejadian, bisa terdiri dari laki-laki dan perempuan. Dengan demikian seorang saksi harus berada di tempat kejadian pada saat kejadian berlangsung, dan dapat mendeskripsikan kejadian yang disaksikannya.

Pembahasan tentang kesaksian menurut Syafi'iyah meliputi masalah nasab, kelahiran, kematian, perbudakan, perwalian, wakaf, pengasingan, pernikahan dan yang berkaitan dengannya, ta'dîl, jarh , wasiat, petunjuk (mengenai hilal), dan kepemilikan. Menurut Hanafiyah, saksi diperlukan dalam lima masalah, yaitu pernikahan, dukhul, keturunan, kematian, dan peradilan. Sementara menurut kalangan Hanabilah dan sebagian Syafi'iyah kesaksian dibutuhkan terkait dengan pernikahan, keturunan, kematian, perbudakan, wakaf, dan kepemilikan.

Lebih lanjut Sayyid Sabiq mencatat beberapa syarat yang harus dipenuhi oleh saksi, yakni: Islam (akad antara muslim dan Muslimah), adil, berakal, baligh, memiliki kekuatan ingatan, netral, bisa berbicara, dan tidak tuna netra. Menurutnya, kesaksian dapat dikualifikasi berdasarkan kuantitasnya menjadi 5 kelompok, yaitu: (1) dalam perkara tuduhan berbuat zina harus berdasarkan kesaksian 4 orang laki-laki; (2) tiga orang saksi laki-laki diperlukan untuk menentukan status sosial seseorang berdasarkan harta benda; (3) diharuskan kesaksian dua orang laki-laki dalam perkara pidana dan perkawinan; (4) dalam bidang kehartabendaan kesaksian dua orang laki-laki atau seorang laki-laki dan dua orang perempuan dianggap cukup; (5) seorang perempuan diterima kesaksiannya dalam permasalahan radlâ'ah.

Penjelasan di atas, menampakkan bagaimana superioritas laki-laki masih begitu kental dalam literatur fikih. Perempuan dianggap memiliki kekuatan akal terbatas dan berada di bawah laki-laki. Lebih dari itu, pendapat ulama fikih tersebut, kemudian diadopsi oleh perundang-undangan di Indonesia, khususnya Kompilasi Hukum Islam, sebagai berikut:

(pasal 25) Yang dapat ditunjuk sebagai saksi dalam akad nikah adalah seorang laki-laki, muslim, adil, akil baligh, dan tidak terganggu ingatan, dan tidak tuna rungu atau tuli.

(pasal 26) Saksi harus hadir dan menyaksikan secara langsung akad nikah serta menandatangani akta nikah pada waktu dan ditempat akad nikah dilangsungkan.

Penting dikemukakan, bahwa KHI di Indonesia disusun melului empat jalur, yaitu: (1) jalur kitab-kitab fikih; (2) jalur wawancara dengan ulama Indonesia; (3) jalur yurisprudensi peradilan agama; dan (4) jalur perbandingan dengan perundang-undangan Maroko, Mesir, dan Turki.( Bustanul Arifin , 2002) Jadi tidaklah begitu mengherankan jika di dalam KHI masih banyak muatan kitab-kitab fikih klasik yang menempatkan perempuan satu tingkat di bawah laki-laki.

\section{Pandangan Ulama terhadap Kesaksian dalam Perkawinan}

Dalam literatur hukum Islam pembicaraan tentang kesaksian perempuan umumnya merujuk kepada surat Al-Baqarah (ayat: 282) dan hadis tentang dua kekurangan/kelemahan perempuan, yakni, akal dan agama. Sementara ayat yang menyetarakan dan tidak mempermasalahkan kedudukan laki-laki dan perempuan kurang 
ditekankan. Berikut dikemukakan bagaimana pendapat fuqaha mengenai kedukukan dan fungsi saksi dalam perkawinan, khususnya kesaksian perempuan.

Menurut Hanafiyah, saksi harus ada dalam perkawinan, sebagaimana dicatat Al-Sarkhisi: (i) hadis yang mengharuskan kehadiran empat unsur dalam akad nikah untuk sahnya perkawinan, yakni calon suami (peminang), wali dan dua orang saksi, ditambah dengan (ii) asar 'Umar yang tidak mengakui keabsahan perkawinan yang hanya dihadiri satu orang saksi. Menurut Abu Hanîfah, saksi dalam perkawinan bisa saja orang fasik, karena kesaksian dimaksudkan sebagai cara mengumumkan perkawinan. Alasan yang dikemukakan menunjukkan bahwa kehadiran saksi hanya untuk menghadiri dan mendengarkan, maka tidak ada kekhawatiran berbohong.

Lebih lanjut, sebagaimana dikemukakan al-Sarkhisi diperbolehkannya saksi gabungan antara dua wanita dan satu pria. Bahkan menurutnya satu wanita ditambah satu pria pun pada dasarnya sudah cukup dalam perkawinan, hanya saja sebagai usaha preventif agar tidak menyesatkan dan tidak lupa, diperlukan satu alternatif, yakni orang lain. Di samping itu, Hadis juga menetapkan kesaksian seorang wanita sama dengan kesaksian setengah pria. Maka kehadiran dua orang wanita menjadi penting. Al-Sarkhisi juga berpendapat, perkawinan yang kesaksiannya ditunda adalah tidak sah. Sebab salah satu syarat saksi adalah penyaksian ketika tejadi transaksi (aqad).

Pendapat berbeda disampaikan Imam Mâlik yang berpendapat bahwa saksi tidak termasuk rukun perkawinan melainkan syarat sempurnanya, sedang yang menjadi rukun adalah pengumuman (I'lân), Pengumuman tersebut berguna untuk menghindari tuduhan atau keraguan orang lain. Dasar yang ditulis Malik untuk mengatakan bahwa kehadiran saksi dalam semua transaksi, termasuk dalam akad nikah, hanya bersifat sunnah (syarat sempurna), adalah Al-Baqarah (2): 282 dan al-Thalaq (65): 2. Sebagai konsekuensi dari pendapat mereka yang menekankan pengumuman, kalau sudah diumumkan maka gugurlah peran dan fungsi saksi.

Dari penjelasan tersebut di atas, tampak bahwa Imam Malik sebenarnya ingin menekankan pentingnya pengumuman dalam pernikahan, yang menurutnya pengumuman inilah fungsi saksi, dan sama sekali tidak ingin mengatakan bahwa saksi dalam akad nikah tidak menjadi syarat. Dalam upaya menekankan pentingnya pengumuman, akhimya Imam Malik terkesan tidak mensyaratkan saksi. Dengan ungkapan lain, Imam Malik tetap berpandangan bahwa saksi menjadi syarat sempurnanya, bukan syarat sah perkawinan.

Al-Syâfi'i mengharuskan adanya saksi dalam perkawinan, yang terdiri dari dua orang pria yang adil. Argumen yang digunakan adalah hadis yang diriwayatkan dari ibn 'Abda. Kesaksiaan dua orang saksi yang bermusuhan dengan para calon (mempelai) dapat diterima dan perkawinannya sah, dengan catatan tetap adil dan mengakui perkawinan tersebut. Imam Al-Syafi'i, juga menambahkan empat hal yang menjadikan sahnya sebuah perkawinan: (1) wali, (2) persetujuan (ridla) dari yang akan dinikahkan (al-mankûhah), (3) persetujuan dari yang akan menikahi (an-nâkih), dan (4) dua orang saksi yang adil.

Menurut Syafi'iyah, perempuan dianggap tidak memiliki kompetensi sebagai saksi dalam urusan perkawinan, berdasarkan syarat yang diajukan atas saksi sebagaimana yang disyaratkan terhadap wali, yaitu : (1) Islam, (2) Baligh, (3) Berakal, (4) Merdeka, (5) Laki-laki, dan (6) Adil. Pendapat inilah yang berkembang di Indonesia dan diadopsi Kompilasi Hukum Islam di Indonesia. Dalam KHI disebutkan bahwa seorang saksi 
perkawinan haruslah beragama Islam, laki-laki, adil, aqil baligh, tidak terganggu ingatannya, dan tidak tuna tungu.

Dalam mazhab Hanbali, saksi dalam perkawinan harus ada dan tidak boleh seorang dzimmi, tidak wanita, tetapi boleh saksi orang buta, dengan syarat mengetahui benar suara orang yang melakukan transaksi (akad) sama kira-kira dengan pengetahuan orang yang tidak buta. Dasar yang digunakan adalah hadis yang diriwayatkan az-Zuhri, bahwa Nabi melarang wanita menjadi saksi dalam masalah perkawinan dan talak. Dalam riwayat lain termasuk juga larangan pada bidangbidang mu'amalat. Dengan ungkapan lain, saksi dalam akad nikah harus laki-laki dan jumlahnya harus dua, dan disunatkan mengumumkan perkawinan.

Menurut Ibn Qudamah, hukum mengumumkan perkawinan hanya sunah, berdasarkan perintah untuk memukul gendang (dufûf) dan mendendangkan suara. Sekiranya pengumuman menjadi syarat akad, pasti disyaratkan seperti halnya syaratsyarat lain. Penjelasan ini memberikan pengertian bahwa dalam madzhab Hanbali, saksi merupakan bagian dari rukun nikah, sedangkan pengumuman hanya berupa anjuran.

Abu Zahra mengklaim, semua ulama sepakat bahwa tujuan akhir dari keberadaan saksi dalam perkawinan adalah pengumuman (I'lân) kepada masyarakat luas tentang telah dilakukankannya prosesi perkawinan. Demikian juga Mahmud Syalthut, lebih menekankan pada fungsi saksi yaitu untuk menyebarluaskan informasi tentang perkawinan kepada masyarakat, daripada sekedar kehadirannya pada akad nikah.

Dari pembahasan di atas tampak, bahwa pada prinsipnya semua ulama mensyaratkan adanya saksi dalam akad nikah, hanya saja Imam Malik terlihat lebih menekankan fungsi saksi sebagai sarana pengumuman daripada hanya sekedar hadir pada waktu akad nikah. Akibatnya, terkesan Imam Malik tidak mengharuskan saksi dalam akad nikah.

Malikiyah, syafi'iyah, dan Hanabilah juga mensyaratkan jenis kelamin laki-laki atas saksi perkawinan, berbeda dengan Hanafiyah yang masih mentolerir perempuan, bahkan mensejajarkannya dengan laki-laki.

\section{Telaah Terhadap Dalil-dalil Tentang Kesaksian Perempuan}

Sebagaimana telah penulis jelaskan, mayoritas fuqaha dan masyarakat muslim secara umum menganggap bahwa harga seorang saksi perempuan hanyalah "setengah" saksi laki-laki, dan oleh karenanya dua orang saksi perempuan adalah sama dengan seorang saksi laki-laki. Dasar utama yang digunakan umumnya merujuk kepada surat Al-Baqarah ayat (282). Asbâb al-Nuzûl ayat ini berkaitan dengan ba'y al-Silm, yakni jual beli pesanan yang pembayaran secara tunai dilakukan ketika barang pesanan telah sempurna. Redaksi lain menyebutkan bahwa ayat ini berkenaan dengan hutang piutang dalam batas waktu tertentu.

Secara tektual, ayat 282 tersebut memberikan pemahaman bahwa kesaksian dua orang perempuan dinilai setara dengan kesaksian seorang laki-laki, ini pun dengan catatan sudah tidak ditemukan lagi dua orang laki-laki. Oleh mayoritas ulama, ayat ini kemudian ditafsirkan dengan hadis yang menjelaskan kekurangan/kelemahan akal perempuan dibanding laki-laki sebagai alasan terhadap otoritas kesaksian laki-laki.

Berbeda dengan mayoritas ulama salaf yang menganggap nash tentang kesaksian sudah final, para pemikir kontemporer menunjukkan kekurangan akal dalam hadis ini tidak berarti perempuan secara potensial tidak mampu menyamai atau melampaui prestasi kreativitas akal laki-laki. Hadis ini menggambarkan keadaan praktis sehari-hari kaum laki-laki dan perempuan di masa Nabi. Laki-laki mempunyai otoritas satu berbanding dua dengan perempuan, karena ketika itu fungsi dan peran publik berada di 
pundak laki-laki. Dengan kata lain, jika peran publik perempuan setara dengan peran publik laki-laki, maka kesaksian perempuan memiliki nilai yang sama dengan laki-laki.

Menurut Asghar Ali E. dinilainya kesaksian dua orang perempuan sebanding dengan kesaksian seorang laki-laki disebabkan oleh terbatasnya pengalaman perempuan dibanding laki-laki dalam masalah keuangan. Argumen yang digunakan adalah pendapat Muhammad Asad, bahwa ketentuan dua perempuan dapat dijadikan pengganti bagi satu saksi laki-laki, tidak memberi cerminan bahwa kemampuan intelektual perempuan lemah atau kurang secara mutlak. Hanya saja perempuan kurang akrab dengan prosedurprosedur bisnis dibanding laki-laki. Menurut Ali Asghar ayat ini bersifat anjuran, bukan wajib. Al-Qur'an ingin bersikap adil bagi yang berhutang dengan ditulis dan oleh dua orang saksi yang pantas.

Untuk memperkuat pendapatnya, Asghar Ali mengutip penafsiran yang diberikan Maulvi Mumtaz Ali Khan. Pertama, ayat Al-Qur'an tentang kesaksian perempuan dengan cara apapun tidak membuktikan inferioritas perempuan dibanding laki-laki. Maulvi juga termasuk yang berpendapat bahwa karena perempuan, di masa ketika ayat tentang kesaksian diturunkan, dibiarkan bodoh, buta huruf, dan tidak pernah menerima pengalaman yang cukup dalam masalah keuangan, oleh karenanya Al-Qur'an menetapkan kebutuhan dua saksi perempuan sebagai pengganti satu saksi laki-laki. Itu hanyalah untuk mengingatkan yang satu jika yang lain lupa atau melakukan kesalahan. Kaum laki-laki menjadi kompeten dalam masalah-masalah seperti keuangan karena dapat mengingat lebih baik dibanding perempuan. Kedua, Maulavi berpendapat bahwa perintah Al-Qur'an ini adalah pilihan dan bukan pemaksaan bagi semua umat. Ketiga, menurutnya kecuali transaksi keuangan, Al-Qur'an di mana pun juga tidak membutuhkan dua kesaksian perempuan sebagai pengganti satu laki-laki seperti dalam masalah perkawinan, perceraian, hudûd (hukuman), dan qishâsh (pembalasan). Keempat, dia berargumentasi bahwa Nabi telah menerima kesaksian seorang perempuan dan merujuk pada hadis yang menceritakan bahwa 'Uqbah telah menikahi seorang gadis dan kemudian datang seorang perempuan yang memberi informasi (kesaksian) bahwa dia telah menyusui baik laki-laki maupun perempuan itu. Menurut hadis ini, Nabi menerima kesaksian perempuan tersebut dan membubarkan perkawinan mereka. Mengenai hadits ini, sebetulnya telah digunakan oleh para ulama yang menegaskan bahwa persaksian seorang perempuan dalam kasus 'Uqbah tersebut bersifat khusus terkait permasalahan radla'ah.

Senada dengan pandangan di atas, menurut Zaitunah, ketentuan kesaksian satu laki-laki dan dua orang perempuan tidaklah mencerminkan kemutlakan jumlah, namun merupakan hasil pembacaan yang proporsional terhadap kondisi perempuan ketika itu, yang secara umum kualitasnya masih di bawah laki-laki. Namun akan berbeda lagi misalnya bagi perempuan yang matang dalam bisnis, memiliki SDM memadai, sebagaimana Khadijah, maka ini dapat merubah formula itu menjadi satu banding satu. Dan kesaksian ini tidak dapat diberlakukan untuk kesaksian secara umum, namun hanya dalam hal bisnis dan sifatnya konstekstual. Dengan demikian, ayat dan hadis tentang kesaksian perempuan bersifat kontekstual dan harus ditafsirkan sesuai dengan kondisi sosial perempuan.

Tawaran cermat diajukan oleh Nasaruddin Umar, yang menyatakan bahwa yang dimaksud kata rajul dalam ayat di atas lebih menekankan kepada aspek jender laki-laki bukan kepada aspek biologisnya sebagai manusia yang berjenis kelamin laki-laki. Menurutnya, tidak semua yang berjenis kelamin laki-laki mempunyai kualitas persaksian yang sama. Dia kemudian mengutip syarat-syarat saksi yang diajukan oleh 
Sayyid Quthub, bahwa Anak laki-laki di bawah umur, orang mabuk, orang gila, dan hamba sahaya tidak termasuk dalam kualifikasi saksi yang yang dimaksud ayat tersebut di atas.

Lebih jauh, penulis Argumen Kesetaraan Jender Perspektif Al-Qur'an ini menyatakan, kata al-rijâl (mufrad rajul) dalam Al-Qur'an lebih berkonotasi jender (gender term), dengan menekankan aspek maskulinitas dan kejantanan manusia yang harus memenuhi kualifikasi budaya tertentu. Dan oleh sebab itu, tradisi bahasa arab menyebut perempuan yang memiliki sifat-sifat kejantanan dengan rajlah. Kata al-nisấ ( $m$ u frad mar'ah atau imra'ah) dalam Al-Qur'an, hanya digunakan dalam arti jender perempuan dan isteri-isteri. Menurutnya, kata yang lebih berkonotasi kepada jenis kelamin adalah al-dzakar dan al-untsâ.

Masih menurut Umar, kata 'aql dalam hadis tentang kekurangan perempuan, masih perlu dilacak apa yang sesungguhnya dimaksud العقل. Apabila kekurangan akal dikaitkan dengan kualitas persaksian, sementara persaksian itu berhubungan dengan faktor budaya, maka bisa saja yang dimaksud dengan kekurangan akal adalah keterbatasan penggunaan fungsi akal bagi perempuan karena adanya pembatasanpembatasan budaya di dalam masyarakat. Jadi sifat kekurangan akal yang diidentikkan dengan perempuan tidak bersifat alamiah dan permanen, dapat berubah sesuai dengan ruang lingkup peran publik perempuan.

Penting dikemukakan, bahwa terdapat beberapa ulama misalnya $\mathrm{Abu}$ Sa'îd AlKhudri dan Al-Sya'by, yang lebih menekankan kualitas daripada kuantitas saksi. Mereka berpendapat bahwa ketentuan, baik wajib maupun sunnah, pencatatan dan kesaksian tidak lagi diperlukan jika tidak dikhawatirkan terjadi perselisihan. Pencatatan dan kesaksian dibutuhkan apabila transaksi tidak didasari sikap saling percaya.

Pengarang kitab al-Fushul fil-Ushul mengatakan bahwa melakukan suatu keutamaan bukanlah kewajiban. Redaksi ayat ini terdapat kalimat nahi (larangan) akan tetapi bukan bermakna larangan bahkan boleh dilakukan. Seperti halnya kalimat amar, apabila tidak bersamaan dengan larangan untuk meninggalkannya maka secara hakikatnya bukanlah suatu perintah, begitu juga kalimat nahi.

Dari dasar di atas, dapat diperoleh ketentuan alternatif bahwa ayat yang menjelaskan tentang kesaksian, khususnya yang menilai kesaksian dua orang perempuan dengan seorang laki-laki dinasakh dengan ayat yang lebih menekankan pada aspek amanah. Apabila aspek amanah lebih penting dari pencatatan dan kesaksian, maka dalam muamalah perempuan memiliki peluang yang sama dengan laki-laki.

Dengan demikian, terlihat banyak ahli tafsir dan ahli hukum modern tidak menerima ketentuan bahwa kesaksian seorang perempuan bernilai setengah dari kesaksian laki-laki, dan jika memang dipahami secara tektual maka hanya khusus dalam lingkup keuangan, tidak lebih. Mayoritas mereka menginterpretasikan bahwa ketentuan tentang persaksian terkait erat dengan budaya yang berlaku ketika ayat tersebut diturunkan, dimana ketika itu peranan publik laki-laki sangat dominan dibanding perempuan. Sementara itu, ulama abad pertengahan (salaf) juga tidak memiliki kesepakatan bulat mengenai kesaksian perempuan, apakah kesaksiannya diterima dalam setiap lini hukum atau hanya dalam hukum jual beli. Namun harus diakui, bahwa dalam ketentuan hukum Islam di Indonesia, khususnya kesaksian dalam perkawinan masih mensyaratkan harus terdiri dari dua orang laki-laki.

\section{Penutup}

Pembicaraan tentang relasi laki-laki dan perempuan tidak hanya membahas perbedaan secara biologis, tetapi juga melibatkan peran sosial mereka. Sebagaimana 
pembahasan tentang kesaksian perempuan di atas, yang mengutarakan perbedaan pendapat para ahli tafsir dan ahli hukum, yang secara umum dapat diambil kesimpulan sebagai berikut:

Pertama, tidak adanya kesepakatan secara bulat diantara ulama salaf mengenai ketentuan sah tidaknya perkawinan tanpa kehadiran saksi. Mereka juga berbeda pendapat tentang diterima tidaknya kesaksian perempuan dalam perkawinan. Namun mereka sepakat bahwa fungsi saksi dalam perkawinan adalah pengumuman atas terjadinya suatu perkawinan.

Kedua, dalam hukum mu'amalah, terjadi pergeseran pandangan atas kesaksian perempuan. Ulama salaf pada umumnya menerima kesaksian perempuan dengan catatan bahwa nilai kesaksian dua orang perempuan sebanding dengan kesaksian seorang lak-laki. Sementara, banyak ulama modern yang mensejajarkan antara kesaksian seorang perempuan dengan kesaksian seorang laki-laki. Perbedaan tersebut disebabkan dua hal yaitu: (1) kondisi sosial perempuan ketika pandangan terhadap kesaksian perempuan diproduk; (2) ulama salaf lebih memaknai kata rajul atau al-rijâl dan mar'ah/imra'ah atau al-nisâ' dalam arti jenis kelamin (sex identity), sedangkan ulama modern memaknainya lebih berkonotasi jender.

Kesimpulan di atas menunjukkan bahwa perlu adanya suatu penafsiran terhadap ayat dan hadis tentang kesaksian perempuan dengan mempertimbangkan kondisi sosial perempuan dan kemungkinan adanya identitas jender, yang kemudian diharapkan menjadi rujukan hukum Islam, khususnya Kompilasi Hukum Islam di Indonesia.

\section{Daftar Pustaka}

Al-'Asqalâny, Ibn Hajr, Fath al-Bâry, Al-Maktabat Al-Syâmilaț, volume 2.

Al-Barudi, Imad Zaki, Tafsir Wanita, terjemah, Jakarta: Pustaka Al-Kautsar, 2004.

Al- Bukhâri, Muhammad Isma'il, Shahîh al-Bukhâry, Al-Maktabat Al-Syâmilat, volume 2.

Al-Daruquthni, 'Ali bin Umar Abu Hasan, Sunan Al-Daruquthni, Kitab al-Nikâh, AlMaktabat Al-Syâmilat. volume 2.

Al-Dimyathi, Abu Bakr, I'ânat al-Thalibîn, al-Maktabat al-Syâmilat. volume 2.

Al-Husainy, Taqiyuddin Abi Bakr, Kifâyat al-Akhyâr fî Hall Ghâyat al-Ikhtishâr, AlMaktabat Al-Syâmilaț, volume 2, juz II.

Al-Jurjani, Al-Ta'rîfât, Al-Maktabat Al-Syâmilat, volume 2.

Arifin, Bustanul, Pelembagaan Hukum Islam di Indonesia: Akar Sejarah, Hambatan, dan Prospeknya, Jakarta: Gema Insani Press, 1996.

Al-Khatib, Hasan Ahmad, Al-Fiqh Al-Muqarin,

Al-Nawawi, Muhyiddin Abu Zakariya, Al-Majmu' Syarn al-Muhadzdzab, Al-Maktabat Al-Syâmilat. volume 2 .

Al-Syafi'I, Muhammad bin Idris, Al-Umm, Al-Maktabat Al-Syâmilat, volume 2 .

Al-Sarkhisi, Abu Bakar Muhammad bin Sahl, Al-Mabsûth, Al-Maktabat Al-Syâmilat. volume 2.

Al-Thabary, Mohammad bin Jarîr, Jâmi' al-Bayân fi Ta'lîm al-Qur'ân, Al-Maktabat Al-Syâmilat. volume 2 .

Al-Tirmidzi, Sunan al-Tirmidzi, Al-Maktabat Al-Syâmilaț, volume 2.

Al-Zuhayli, Wahbah, Usul al-Fiqh al-Islam Damshiq: Dar al-Fkr, 1986.

Bown, John. R. Islam, Law, and Equality in Indinesia: An Anthropology of Public Reasoning, Cambridge: Cambridge University Press, 2002.

Departemen Agama R.I. Kompilasi Hukum Islam di Indonesia, Jakarta: Ditjen Pembinaan Kelembagaan Agama Islam Tahun 1997/1998. 
Dono, Daniela, dan Bruce Russett, Gender, Islam, And Autoritarianism. World Politics 56 July 2004.

Engineer, Ashghar Ali, Hak-Hak Perempuan dalam Islam, terjemah oleh Farid Wajdi Jakarta:LSPPA, 1994. , Pembebasan Perempuan, terjemah oleh Agus Nuryanto, Yogyakarta: LKis, 2003.

Fish, M. Steven, Islam and Authorism, World Politics 55 October 2002.

Feillard, Andree, Indonesia's Emerging feminism: Women Leader on Equality, Inheritance, and Other Gender Issues, Studia Islamika, Volume 4 Nomor 1, 1997.

Ibn Abidin, Mohammad Amin, Radd al-Mukhtâr, Al-Maktabat Al-Syâmilaț. volume 2.

Ibn Katsîr, Abû al-Fidâ' Isma'il, Tafsîr Al-Qur'an al-'Adzîm, Al-Maktabat Al-Syâmilat, volume 2.

Ibn Manzhûr, Lisân al-'Arab, al-Maktabata al-Syâmilat, volume 2.

Ibn Rusyd, Bidâyat al-Mujtahid wa al-Nihâyat al-Muqtashid, Lebanon: Dar Ibn 'Ashshâshah, 2005.

Ibn Qudamah, Al-Mughni, Al-Maktabat Al-Syâmilat, volume 2, juz XIV.

Khallaf, Abd al-Wahhab, 'Ilm Usul al-Fiqh Kuwait: Dar al-Qalam, 1977.

Lang, Jeffrey, Berjuang Untuk Berserah: Menyegarkan Pemahaman Islam, terjemahan, Jakarta: Serambi Ilmu Semesta, 2000. cet. IV.

Muhammad, Husein, Fiqh Perempuan: Refleksi Kiai atas Wacana Agama dan Gender, Yogyakarta: LKis, 2001.

Muslim bin Hajjâj, Shahîh Muslim. Al-Maktabat Al-Syâmilat, volume 2.

Nasution, Khoiruddin, Status Wanita di Asia Tenggara: Studi Terhadap Perundangundangan Perkawinan Muslim Kontemporer di Indonesia dan Malaysia, Jakarta: INIS, 2002.

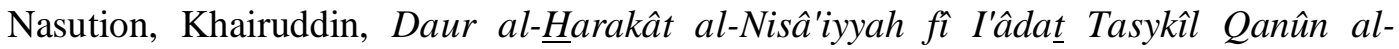
Mujtama' al-Islâmî bi Indûnîsiyyâ, Studia Islamika, Volume 8, Nomor 2, 2002

Nur, Said, Perempuan dalam Himpitan Teologi dan HAM, Yogyakarta: Pilar Religia, 2005.

Sabiq, Sayyid, Fiqh al-Sunnah, Al-Maktabat Al-Syâmilat, volume 2.

Subhan, Zaitunah, Menggagas Fikih Pemberdayaan Perempuan, Jakarta: el-Kahfi, 2008, cet II.

Syalthût, Mahmûd, Al-Fatâwâ: Dirâsat Musykilât al-Muslim al-Mu'âshir fî hayâtihi alYaumiah al-'Ammah, ttp: Dar al-Qalam, tt.

Umar, Nasaruddin, Argumen Kesetaraan Jender: Perspektif Al-Qur'an, Jakarta: Paramadina, 2001.

Wahid, Abdurrahman, Islam Kosmopolitan: Nilai-nilai Indonesia dan Transformasi Kebudayaan, Jakarta: the Wahid Institute, 2007.

Zahra, Muhammad Abu, Muhâdarât fì 'Aqd al-Zawâj wa Asâruhu, ttp: Dar al-Fikr Al'Arabiyah, tt. 